\title{
Neither Victim Nor Accomplice: The Kızılbaş as Borderland Actors in the Early Modern Ottoman Realm
}

\author{
Ayşe Baltacıoğlu-Brammer
}

The leaders of the Safaviyya order with its center in Ardabil, a relatively small city in northwestern Iran, put immense efforts into recruiting followers from among Turkoman (and Kurdish) tribesmen in Anatolia beginning in the mideighth/fourteenth century. By the second half of the ninth/fifteenth century, as the movement completed its transformation into a Shi'i military-cum-political group under the leadership of Junayd (d. 869/146o) and his son Haydar (d. 893/ 1488), Safavid efforts consequently evolved from mostly uncoordinated endeavors aiming to gain followers for the order to a series of semiofficial and programmatic policies of recruiting full-fledged adherents to their cause. These adherents were called Kızlbaş, meaning "read head" in Turkish, due to a crimson twelve-gored headpiece that they wore, which signified their devotion to the Twelve Shi'i Imams, as well as to the leaders of the Safavid movement. ${ }^{1}$ This new type of loyalty under the Safavid banner often times meant sending money to the Safavid state via its agents, serving as soldiers in the shah's army, and in many cases migrating to the Safavid realm. The relatively small number of Kızlbaş in greater Iran, where most of the population were either nominally Sunni or politically distant from the movement, made Anatolia (and to a lesser extent Iraq and Syria) even more attractive for the Safavid leaders in their attempts to find a loyal base. ${ }^{2}$ The Safavid leaders, continuing

1 For a detailed discussion on the gradual crystallization of the Safavid Sufi order into a Shi' $i$ religiopolitical movement under the Safavid banner, see Baltacioğlu-Brammer, The emergence of the Safavids; Mazzaoui, The origins of the Safavids; Abbaslı, Safevilerin kökenine dair; Anooshahr, Turkestan and the rise of Eurasian empires 56-83; Musalı, Şeyh İbrahim Safevidöneminde Erdebil Tekkesi; Pourahmadi-Amlashi and Zeylabpour, Sheikh Ibrahim Safavi Morshid-e Ghomnam; Hinz, Uzun Hasan ve Şeyh Cüneyd; Sümer, Safevi devletinin kuruluşu.

2 Sultan Ya'qūb (d. 896/149o), the ruler of the Aq Quyunlu state, in his letter to Sultan Bāyezīd II (d. 918/1512) specifically mentions Haydar's brutality against the locals including "nursing babies, women, and elderly" to explain Safavids' unpopularity in Azerbaijan. Ferīdūn Beg, Münşe'ätü's-selāțīn i, 302-304. One should also mention the linguistic connection between the Turkish-speaking Safavid leaders and most of the inhabitants of Anatolia as a reason for this affinity. 
with Shah Ismāīil (r. 907-930/1501-1524) and Shah Tahmāsb (r. 930-984/15241576), primarily strengthened their position by addressing certain vulnerabilities and sensibilities of the inhabitants of the region stemming from various sociopolitical and financial grievances, as well as millenarian anxieties, ${ }^{3}$ by offering a communal identity, a sense of security, and a series of possibilities for advancement. The end result was that by the mid-tenth/sixteenth century, if one is to believe some of the Ottoman, Safavid, and European sources, the Kuzılbaş constituted the majority of the population in Anatolia with a heavy presence not only in rural areas but also in urban centers, including Istanbul. ${ }^{4}$

Modern historiography's initial attempts to tackle the Kızlbaş question was, however, inconsistent, if not problematic. At the outset, according to the Turkish historians-cum-politicians of the early twentieth century, whose staunch nationalist agenda shaped the nature of history writing in the first decades of the newly founded Turkish republic, the existence of the Kizlbaş population in the early modern Ottoman realm was never more than an "aberration" because, according to them, Shi'ism and "Turkishness" have been historically incompatible with each other. ${ }^{5}$ On the other hand, a number of scholars in the second half of the century, while recognizing the existence of a substantial Kızılbaş community in early modern Anatolia, have overemphasized either the influence of pre-Islamic beliefs and traditions, the ignorance of local populations, or the intensity and permanence of the Sunni Ottoman administration's persecution of its non-Sunni (in this case, the Kızılbaş) subjects of the empire. ${ }^{6}$ Consequently, the Ottoman Kuzılbaş existed in these foundational works mostly as the passive followers of the Safavid court against whom Istanbul's "keen sword" swung ceaselessly.

3 For detailed discussions on millenarian anxieties in the early modern period, see Subrahmanyam, Turning the stones; Fleischer, The Lawgiver; Özel, Population changes; Babayan, Mystics, monarchs, and messiahs; Bashir, Deciphering the cosmos; Bashir, Messianic hopes; Ocak, Syncrétisme et esprit messianique.

4 Minorsky, Shaykh Bali-Efendi 438, n. 4; Baha Said Bey, Türkiye'de Alevi zümreleri 404-406; Baştav (trans. and ed.), 16. asırda yazılmış 178-180.

5 Köprülü, Türk edebiyatı'nda ilk mutasavvıflar; Günaltay, Türk-İslam tarihine eleştirel bir yaklaşım, and for a later era example of this approach, see Saray, Türk: Iran münâsebetlerinde. The so-called "Köprülü paradigm" has been widely criticized by several scholars. See, for instance, Karamustafa, Origins of Anatolian Sufism; Dressler, Writing religion; Karakaya-Stump, The Kizilbash-Alevis.

6 Bardakçı, Alevilik; Ocak, Babailer isyanı; Ocak, Alevi ve Bektaşi inançlarının; Ocak, Din ve düşünce; Mélikoff, Uyur idik uyandırdılar; Arjomand, The shadow of God 79; Cahen, Le problème du Shîisme 120; Eröz, Türkiye'de Alevilik Bektaşilik; Roemer, The Qizilbash Turcomans; Imber, The persecution; Kütükoğlu, Osmanlt-Iran siyasi münasebetleri. 
The revisionist historiographical wave of the late twentieth and the early twenty-first century has rightfully criticized these previous approaches and broadened our horizon not only about the early modern Kızlbaş movement, but also about the nature of the Ottoman state and society in general. ${ }^{7}$ With a new set of concepts, debates, and perspectives to evaluate the past, recent studies have (re)contextualized the sociopolitical and religious undercurrents of the era to meaningfully evaluate the early modern Ottoman state and its involvement in the creation and dissemination of religious narratives and policies. Drawing on the studies examining the efforts taken by the state authorities in early modern Europe toward confessional uniformity, several historians of the eastern Mediterranean have recently proposed to reassess the Ottoman state's increasing emphasis on sectarian standardization in the early modern era under the rubric of "confessionalization." While Marcus Dressler has characterized these efforts of the Ottoman state as "inventing orthodoxy,"8 Tijana Krstić has convincingly argued that the Ottoman central authority's efforts at confession building in fact aimed "higher" than simply defining a confessional identity for its subjects, because a "tendency to sacralize authority exercised by the ruler" was also a way of maintaining social discipline. ${ }^{9}$ The Ottoman state's increasing emphasis on Sunnism in the highest political and scholarly circles was also noted by Hüseyin Yllmaz, who pointed to a sharp increase in the number of Ottoman polemical and nonpolemical accounts written during and/or right after Istanbul's military engagements with the Safavids, which depicted the Ottoman dynasty as the one chosen by God. ${ }^{10}$ At the same time, however, Derin Terzioğlu has argued that Ottoman Sunnitization was a "continuation of pre-existing trends" with multifaceted causes rather than "simply a politically minded response to the rise of the Safavids," and that a wider set of issues must be considered in order to get a better understanding of the phenomenon. ${ }^{11}$

Although these scholars established that the Ottoman-Safavid rivalry radically changed the Ottoman imperial and scholarly language, their works' heavy emphasis on confession building has perpetuated - as an unintended consequence, I would say - the dichotomy between the Sunni Ottoman rulers and their non-Sunni/Kızlbaş subjects. As a response, this article, while building upon recent studies that have reevaluated Ottoman religious politics, inte-

\footnotetext{
7 See the scholarship produced by Yıldırım, Karakaya-Stump, and Zarinebaf listed in the bibliography.

8 Dressler, Inventing orthodoxy 141.

$9 \quad$ Krstić, Contested conversions 14.

10 Yllmaz, Caliphate redefined 218-228.

11 Terzioğlu, How to conceptualize 305.
} 
grates a new set of questions into the picture to challenge the long-held view that the relationship between the Sunni rulers and their Kızllbaş subjects was irreconcilable and characterized by the state's perpetual persecution of the "defenseless" and/or "powerless" confessional nonconformists. ${ }^{12}$ This is only possible with an in-depth examination and synthesis of the Ottoman imperial sources which reveals that, as a unique population situated in between the two mighty empires, the Ottoman Kizllbaş were neither the passive followers of the Safavid court nor the defenseless victims of the "never-ending" Ottoman persecution. On the contrary, even though Istanbul from time to time pursued policies targeting the Kızlbass en masse, the same community embodied regional, socioeconomic, and political heterogeneity, and shaped the nature of the relationship between the Ottoman and Safavid courts. The Kızlbaş also indirectly influenced the formation and development of sectarian identities at both the state and the individual levels in the early modern era, from Ottoman Sunnism to Safavid Shi'ism and everything in between. While acknowledging possible limitations of relying on the sources written by the "ruler," not by the "ruled," I should note that this is an intentional approach as the goal here is to reexamine the status of the Kızlbaş and the power that they wielded vis-à-vis the political establishments of the region (i.e., the Ottoman and Safavid states) by scrutinizing the mundane-looking and often straight-forward state documents and narratives, which on the surface are heavily informed by sectarian language. ${ }^{13}$ The voice of the Kızlbaş as a substantial power holder of the era manifests

12 Several historians have recently challenged this dichotomy from different angles. Vefa Erginbaş has successfully demonstrated the heterogenous nature of Sunnism in the Ottoman domains. See Erginbaş, Problematizing Ottoman Sunnism; Erginbaş, Reading Ottoman Sunnism. Stefan Winter brought further nuance to this picture by demonstrating the importance of pragmatism as the leading — yet often times neglected-factor that determined Istanbul's approach toward its Shi'i population, rather than confessional zealotry. Winter, Shiites of Lebanon. For a nuanced take on the ambiguities between Sunnism and Shi'ism in the context of medieval Anatolia, see Yıldırım, Sunni orthodoxy vs. Shi'ite heterodoxy?

13 The limited number of existing and available Kızllbaş sources provide us with certain clues on the sociopolitical and fiscal authority that the Ottoman Kızlbaş retained. See Karakaya-Stump, Kızllbaş; Bektaşi, Safevi ilişkilerine dair. However, one should mention that Kizllbaş sources carry their own limitations, since they mostly discuss the rules, regulations, and teachings of the Kızlbaş/Shi'i faith, religious and/or heroic poetry, or the pedigree of certain Kızılbaş families. The recent growing corpus on the Kızlbaş sources in general include Kaplan, Yazılı kaynaklara göre Alevilik; Kaplan, Şeyh Safi buyruğu; Ayyıldız, Buyruk; Birdoğan, Alevi kaynakları; Musalı, Şeyh Safi Velâyetnâmesi; Karakaya-Stump, Documents and buyruk manuscripts; Birdoğan, Anadolu ve Balkanlar'da Alevi yerleşimleri; Yaman, Buyruk; Taşğın, Bisâtî, Şeyh Sâfî Buyruğu; Yıldırım, Geleneksel Alevilik. 
itself in these sources via the practices of conversion and reconversion, as well as the acts of negotiation, tax evasion, migration, and ultimately rebellion. ${ }^{14}$

Within this context, this chapter also problematizes the clear-cut boundaries between the sectarian camps in the early modern Middle East (i.e., Sunni Ottomans vs. Shi'i Safavids), as well as the depiction of the Kuzılbaş population as caught in the middle, by elucidating the latter's vigorous and dynamic interactions with both sides based on individual and communal interests. To do so, I employ two broad frameworks. To begin with, I utilize the concept of "social conversion," which was coined by Richard Bulliet in his attempt to examine the Islamization, and later Shi'itization, of Iran..$^{15}$ I use this concept to encapsulate the complexities of forming and shifting religious identities as behaviors with multifaceted thought processes, particularly in the early modern context denoting, in many cases, relocation "from one religiously defined social community to another" with nonreligious motivations playing a significant role in the process. Bulliet's approach, based on the argument that "leaving aside ecstatic converts, no one willingly converts from one religion to another if by virtue of conversion he markedly lowers his social status,"16 serves here as a significant tool for understanding the practice of political and religious conversion in the early modern Ottoman context, in which the members of the Kızlbaş community were active participants and negotiators rather than oblivious followers or the powerless victims of the imperial powers in play. ${ }^{17}$

The second framework that I employ in this article involves the notions of frontier, border, and borderland authority. As significant historical points of reference, borderlands in the early modern era revealed different state-society dynamics. These broadly defined "end territories," Palmira Brummet rightfully argues, were places "where one empire flowed into (and out of) another ... wars were fought, garrisons built, and allegiances tested." ${ }^{18}$ While the borders

14 A similar approach has been recently taken by several scholars in their attempts to scrutinize the Ottoman court's interaction with Kurdish tribes and tribal leaders. For instance, Baki Tezcan mentions an imperial document dating from the 930s/1530s giving privileges of hereditary rule to various Kurdish emirs in return for their loyalty to the Ottoman sultan, not the Safavid shah. See Tezcan, The Development. In a similar vein, Nelida Fuccaro examines the complexity of the Kurdish frontier between the Ottoman and Safavid Empires. See Fuccaro, The Ottoman frontier in Kurdistan.

15 Bulliet, Conversion to Islam; Radushev, The spread of Islam 363-384.

16 Bulliet, Conversion to Islam 34, 41.

17 This approach can be criticized as being reductionist with its heavy emphasis on sociopolitical factors. While seeing this point, this study aims to strike a balance between the existing literature, in which the Kızlbaş have no power, and historical reality where, I argue, their power manifested itself via various forms and behaviors. 
of the Ottoman Empire with its western neighbors have been a popular topic among historians, the eastern Ottoman borders in the early modern era have not received comparable attention. ${ }^{19} \mathrm{~A}$ close reading of the sources reveals that in this context the Kızılbaş were an integral party in negotiating and maintaining the border between the Ottoman and Safavid empires, although by that I do not necessarily mean the conventional borders resulting from peace treaties but borders demarcated by sphere of influence that could sometimes be limited in one's own but extend deep into the other polity's territory. I call this type of demarcation of power and legitimacy as "domestic" or "inner" borders. Therefore, every Ottoman sultan and Safavid shah, being fully aware of the importance and the volatility of their borders, both in the sense of conventional and inner borders, had to (re)negotiate their position not only with the high-ranking members of their court and the provincial elites but also with the population(s) of the borderland regions, in this case the Kızlbaş, Kızılbaş-tobe, or former Kizllbaş. In return, these subjects amassed a significant degree of power as: the cultivators of the land and the providers of tax revenues; foot soldiers; the de facto intermediaries; defenders of the active border zones; and as the subjects who recognized one or the other state authority and thus played a key legitimating role. In other words, the three major participants in the political landscape of Anatolia (i.e., the Ottomans, the Safavids, and the Kızlbaş) were concerned either with the expansion of their empire and the upholding of their legitimacy (in the case of Ottoman and Safavid courts), or with the protection of their status and way of life (in the case of ordinary subjects and community/tribal leaders alike). These motivations and concerns resulted in the cultivation of certain practices that often times crossed the presumed boundaries of sectarian adherences both by the state and its subjects.

Last, but not least, it is also important to emphasize that the term Kizılbaş always carried multilayered social, political, and fiscal meanings for individuals and institutions within the Ottoman and Safavid realms. As I have shown elsewhere, the Ottoman central authority began to refer to the sympathizers (both Ottoman and non-Ottoman) of the Safavid court as "Kızılbaş" only immediately prior to the reign of Sultan Selim I (r. 918-926/1512-1520), who changed the nature of the relationship between Istanbul and the Safavid court with open military engagements and fiscal sanctions. In this context, the term "Kızlbaş"

19 Recent works on the topic of borders between the Ottoman Empire and its neighbors include Peacock (ed.), The frontiers of the Ottoman world; Heywood, The frontier in Ottoman history; Ágoston, A flexible empire; Kołodziejczyk, Between universalistic claims and reality; Zarinebaf, Rebels and renegades; Schwarz, Writing in the margins of empire; Ateş, Ottoman-Iranian borderlands. 
provided the negative labeling that the Ottoman central authority required to identify and pursue the enemy of the "religion and state" (din- ̈̈ devlet), given that the geopolitical legitimacy of Istanbul was at stake with the rapid emergence and expansion of the Safavid state on its eastern frontier. ${ }^{20}$ As Guy Burak has cogently argued, this period also corresponds with the Ottomans' adoption of the Hanafi madhhab as the official school of law under the aegis of the office of the chief mufti (or şeyhü'l-islām), bridging the gap between the Islamic (sharia) and sultanic (kānūn) law. ${ }^{21}$ Therefore, Ottoman policy makers, more often than not, disguised their nonreligious concerns with an increasingly sectarian rhetoric provided by various influential members of the same religious elite group. In the wake of this foundational period, the Ottoman court, starting with Süleymān the Magnificent (r. 926-974/1520-1566) and continuing for over a century, embraced a more complex approach toward both its Kuzılbaş subjects and its rival, the Safavids, whereby the term Kızılbaş carried notably different, and in many cases conflicting, meanings depending on the context, as well as the genre of the documents in which such references were made. ${ }^{22}$

Driven by the objective to emphasize the importance of fluidity and multicausality behind the actions and loyalties, as well as the necessity to reconceptualize the importance of religion and religious belonging in the early modern Middle Eastern context, the following pages will focus on specific sources of the Kızılbaş authority and power: ability to migrate to the enemy territory and stop paying taxes and providing military services to the current ruler. It is my firm belief that the (re)formation of sectarian identities and their politicization in the early modern Middle East can only be fully grasped with this approach that reevaluates the position of the Kızlbaş within the Ottoman state and society by paying attention to the group's intrinsic diversity, their economic interests and political grievances, as well as the complexity of the relationships that they forged with Istanbul and its regional representatives.

20 Baltacioğlu-Brammer, One word, many implications.

21 Burak, The second formation of Islamic law.

22 Baltacıoğlu-Brammer, One word, many implications. For instance, Ottoman imperial documents often times labeled subjects (mainly, but not limited to the Shi'ites of Greater Syria) as Kızılbaş as a legal device in order to justify official violence in situations of brigandage and tax evasion, rather than on account of heretical beliefs. In the eyes of the Ottoman authorities, the Kızılbaş who sent money (and valuable gifts) to the Safavid shahs and sought to migrate to Safavid Iran represented the loss of a critical part of the empire's revenue-producing work force and various orders were sent to the provinces to closely watch these subjects of the empire. 


\section{Ottoman-Safavid Rivalry, Its Frontiers, and Pecuniary Reasons of Religiopolitical Loyalty}

According to Gábor Ágoston, "a common feature of the frontiers [of the Ottoman Empire] were the condominium, that is the joint rule, of the former power elite and the Ottoman authorities." ${ }^{23}$ This understanding is commonly used among scholars to contextualize the western borders of the empire, where Istanbul established and maintained tributary systems with various non-Muslim local power holders. A similar structure, however, existed on the empire's eastern frontier(s) as well, even though the time frame of the expansion and the manner in which it came to be established differed significantly. ${ }^{24}$ During the initial era of the Ottoman and Safavid interaction in southern and eastern Anatolia as well as in northern Iraq (between roughly the 88os and 95os/148os and 1550s), many local tribes, communities, and individuals positioned themselves strategically between the two political entities, contingent upon obtaining material and territorial gains and privileges, as well as spiritual salvation (particularly in the case of loyalty and subjugation to the Safavids). This gave the inhabitants of this porous territory a rationale for supporting or fighting against either the Ottomans or the Safavids in their expansionist endeavors with various degrees of power of negotiation in hand. Accordingly, a high level of fluidity in the political allegiances of the local populations prevailed in the region.

Personal interests and intratribal frictions factored notably into the decision to switch sides when tribes in the regions between the two empires became aware of their ability to play the two imperial authorities off against each other. For instance, when Muhammad Khan (d. 935/1528-1529), the Safavid governor of Baghdad, left the city and escaped to Basra after he learned that his tribe was collaborating against him with the Ottoman authorities, the Safavid shah Tahmāsb I offered him a better position in Basra. ${ }^{25}$ In response, the Ottoman authorities countered by offering the rank of bey to three signifi-

23 Ágoston, A flexible empire 22.

24 Heywood, The frontier in Ottoman history 234-240; İnalcık, Ottoman methods of conquest 103-129. Erzurum and Diyarbekir were two of the few provinces in the region where the timār system was implemented. For the rest of the region, especially those parts inhabited by the Kurds, Istanbul implemented other systems, mainly yurtluk-ocaklık, in which landholdings were typically transmitted from father to son. The holders of yurtluk-ocaklık. would keep the tax revenues of their landholdings while providing military services to the state. Ateş, Ottoman-Iranian borderlands 37-40; Agoston, A flexible empire 20-25; Kılıç, Yurtluk-Ocaklık.

25 Eberhard, Osmanische Polemik 51. 
cant members of Muhammad Khan's family in the region. ${ }^{26}$ Contemporary sources also mention the frontier districts as the scenes of ongoing competition between the Ottomans and Safavids, as well as among the local elites and tribal leaders, who switched allegiance depending on personal and tribal interests. The story of Sulțān Tekelu, an Ottoman sipāhī who "turned Kizllbaş" and defected to the Safavids with many members of his tribe during the Şah Kūlu Rebellion in Anatolia in 917/1511-1512, is a noteworthy case. The Safavid court rewarded Sulțān Tekelu's defection with high-level political/military positions in the regions of Tabriz, Shirvan, and Baku. ${ }^{27}$ The Tekelu tribe, however, was politically weakened as a result of conflicts among various Kızılbaş tribes for dominance in Azerbaijan, and following the death of Shah Ismāil in 930/1524, Sulțān Tekelu this time marched against the new shah's forces. Defeated, he fled to the Ottoman fortress of Van to seek refuge in $940-941 / 1534 .^{28} \mathrm{He}$ was later appointed $l \bar{a} l \bar{a}$, or tutor, to the Safavid prince Alqāṣ Mīrzā, who also sought refuge at the Ottoman court. ${ }^{29}$

The military and political career of the Bidlīsi family, Kurdish overlords of the southeastern Anatolian province of Bitlis, further demonstrates how a frontier family played the Ottomans and Safavids against each other during much of the tenth/sixteenth century, specifically after the rise of the Safavids as the Ottomans' main geopolitical and religious rival in the east. Beginning with Sharaf Beg, grandfather of Sharaf al-Dīn, the author of the famous Sharafnāma, the Bidlisì family made tactical shifts of allegiance to avoid being trapped between the two regional powers. ${ }^{30}$ While Sharaf Beg supplied the Ottomans with detailed intelligence reports on events in Safavid territory, ${ }^{31}$ his son, Shams al-Dīn, migrated to Safavid Iran after Süleyman I appointed 'Ulamā' Beg, a Kızılbaş from Safavid Iran who had switched sides, the governor of Bitlis following the Ottoman campaign to Iraq in 939-940/1533-1534. Shams al-Dīn, along with the members of his tribe, was welcomed by Shah Tahmāsb I and honored with the title khan and the governorship of various districts in Safavid Iran. His son

26 Interestingly enough, Muhammad Khan decided to work for the Ottomans again when Sharaf Khan changed sides and collaborated with the Safavids. Savaş, XVI. asırda Anadolu'da Alevilik 21.

27 Bidlisi, The Sharafnâma 145-146.

28 Riyāhị, Sefāratnāmehā-i Irān 28; Monshī, History of Shah 'Abbas i, 80-83.

29 Solak-zâde, Solak-zâde Tarihi ii, 214.

30 For a comprehensive discussion on the Bidlīsī family, particularly Idris Bidlīsī, and their intricate interactions with the political authorities of the time, see Markiewicz, The crisis of kingship.

31 Glassen, Bedlīsī, Šaraf-al-Dīn Khan. 
Sharaf al-Dīn, however, moved back to his hometown, Bitlis, after a series of meetings with the Ottoman general Hüsrev Pasha in 985-986/1578; as a reward, he was appointed governor. ${ }^{32}$

Even though the contemporary accounts do not specify whether the members of the Bidlisis family (or the above-mentioned Tekelu tribe) explicitly changed their sectarian affiliations whenever they changed their geopolitical allegiance, it is noteworthy that Sharaf al-Dīn's overt 'Alid loyalty33 is quite visible in his chronicle, which he wrote as the Prince of Bitlis under the Ottoman rule. While narrating the events of $803 / 1401$, for instance, he writes, "[Timur] opened the grave of Yazìd the cursed (mel'ün), the son of Mu'āwiya," who ordered the killing of the third Imam Husayn and his family, and burned his bones. ${ }^{34}$ In another passage, while narrating the Timurid ruler Shahrūkh's (d. 850/1447) pilgrimage to Mashhad, Sharaf al-Dīn states that Shahrūkh left Herat to visit "our dear Imam and his splendorous and heaven-scented tomb." 35 The persistence of 'Alid loyalty among the Sunnis of the Ottoman Empire- the phenomenon highlighted by Vefa Erginbaş in this volume and elsewheremust have facilitated the fluidity of the political and religious sympathies among both common people and the tribal elites in the Ottoman-Safavid borderlands. Furthermore, these and many other examples show that while confessional affiliation played a significant role in shaping political allegiances, practical benefits were at least as-or more-important than the message of salvation.

The dynamic nature of the interactions between the Kızlbaş and the Ottoman and Safavid courts continued to exist after the Treaty of Amasya (962/ 1555), which designated a set of zones as the border between the two empires. ${ }^{36}$ Following this treaty, the essential factor motivating the locals (both at the individual and communal levels) to side with either polity (or in some cases to stay relatively neutral) remained relatively the same, this time with heavier emphasis on receiving prestigious posts, titles, or money from the Ottoman and/or

32 Even when the level of Anatolian participation in the Safavid cause was at its peak, Ottoman counterpropaganda did not cease and often met with relative success. According to Sharaf Khan Bidlīsī, for instance, in 1535, around 3,00o Kızılbaş decided to defect to the Ottoman side after Süleyman I promised to make them rulers of Azerbaijan. Bidlisi, The Sharafnâma 184 .

33 On the notion of confesional ambiguity see Woods, The Aqquyunlu 1-24; Pfeiffer, Confessional ambiguity vs. confessional polarization. Also see Vefa Erginbaş's article in this volume, Reading Ottoman Sunnism.

34 Bidlisi, The Sharafnâma 184.

35 Ibid. 86.

36 Ebel, Representation of the frontier. 
Safavid capitals. This was particularly the case when the "new faith is perceived to be tied to a larger and more bountiful political economy." ${ }^{37}$ Therefore, the allocation of money, land, and titles, as well as marriage alliances with key members of the courts and the provincial elites served as successful strategies. According to Fariba Zarinebaf, the main consequence of this mentality was local border communities that were "divided, short of strong leadership, and lacking in effective resistance. ${ }^{38}$ While this was the case in certain situations, the local actors' attempts to insert themselves into ongoing political (and religious) struggles and/or negotiations between the Ottoman and Safavid courts as active participants culminated in both short and long term material (and also strategical) gains for the individuals and the communities in the region alike.

Following the Treaty of Amasya, the Safavid leaders, while retaining their overall goal of creating and maintaining a strong base in Ottoman Anatolia, shifted their attention from recruiting large tribal populations to the Safavid cause, encouraging them to migrate to Safavid Iran, to targeting individuals and small groups, whose loyalty to the Safavid court manifested itself in multifarious ways. Particularly during the last decades of the tenth/sixteenth and early eleventh/seventeenth century, which saw serious domestic unrest within the Ottoman Empire, the religiopolitical loyalties of small groups and individuals were used to justify political actions, financial moves, and in some cases migrations. This situation is evident in Ottoman imperial documents as individuals with their names and religious/regional affiliations within the context of the Ottoman-Safavid rivalry began to appear more often after the mid-tenth/sixteenth century. For instance, Istanbul often utilized money and valuables to prevent individuals and groups from "becoming Kızılbaş." In an imperial order from 982/1574, the governor of Diyarbekir was asked to honor a certain Shaykh Ebū'l-hayr Sālif Efendi with ten akçes for not becoming Kızılbaş (Kızılbaş mezhebine girmeyib). ${ }^{39}$ At the same time, the Ottoman central authority remained highly skeptical of tribes and large groups of people in the border regions who returned to the Ottoman realm (tekrär 'avdet eyleyen) after "becoming Kızılbaş" and migrating to Safavid territory. Several imperial orders sent to frontier towns in Anatolia and Iraq in 980/1573 repeatedly warned the local authorities to capture those who came back from Yukarı Cānib, or the "upper side," meaning mountainous Safavid territory, and to exile them imme-

37 Hefner, World building 29.

38 Zarinebaf, Rebels and renegades.

39 BOA, MD, Vol. 25, No. 1627 (17 Șefer 982/7 June 1574). 
diately to remote parts of the empire, above all newly conquered Cyprus. ${ }^{40} \mathrm{In}$ other cases, an order sent to the governor of Şehrizor (Kirkuk) in 986/1578 mentioned the commander of a frontier fortress, Hasan, to whom the fortress was given with the condition of giving up his kızul tac (i.e., the red headgear symbolizing loyalty to the Safavid shah). The order, after making a comparison with a certain Iskender, who - unlike Hasan — sent his tac to Istanbul to keep his sanjak (or district), accuses Ḥasan of not being reliable and asks the governor not to trust him again, to remove him from his official position, and to confiscate the tac $^{41}$

Moreover, an increasing number of Kızlbaş subjects of the Ottoman Empire made a payment, called nezir (or nüzür), to the Safavid religious and/or political authorities as a sign of sympathy and a source of support. ${ }^{42}$ Ottoman imperial documents show that as the intensity of the flow of money to the Safavid court increased, Istanbul became further concerned about possible revenue losses and its subjects' loyalties, particularly in the Anatolian countryside. Because the Ottoman central authority measured its own legitimacy in terms of tax collection, land cultivation, and battle-ready subjects, its struggle with the Safavids escalated as it attempted to secure its revenue sources and manpower. ${ }^{43}$ This concern with tax evasion and loss of manpower can be seen as early as the correspondence between Sultan Bāyezīd II (886-918/1481-1512) and Shah Ismāīl I. When Shah Ismā̄ill asked Sultan Bāyezīd to let the followers of the Safavid order visit the order's center in Ardabil, the sultan responded that the Anatolian Kuzllbaş could not be allowed to leave the Ottoman realm since they would not come back. Later, Bāyezīd expressed a willingness to allow his subjects to travel to Ardabil only if they made a commitment not to settle permanently in Safavid Iran. ${ }^{44}$ On the other hand, relative acceptance was shown

40 BOA, MD, Vol. 21, No. 652 (22 Zilhicce 980/25 April 1573). It should also be noted that the Ottoman state was trying to repopulate the island. For further details on early modern Ottoman Cyprus, see Jennings, Christians and Muslims in Ottoman Cyprus.

41 BOA, MD, Vol. 35, No. 816 (26 Şa çān 986/28 October 1578).

42 For instance, an official letter sent to Erzurum in 96o/1553 asks the governor to collaborate with the governors of Karaman and Anadolu to calculate the amount of nezir sent from the region of Sivas to the öteki taraf (literally, "the other side," i.e., the Safavids) by the mülähide and räfiża. BOA, Cevdet Tasnifi, Document No. 922-39839 (20 Ramażān 960/3o August 1553).

43 According to the mainstream Turkish historiography, however, Istanbul perceived this as the Safavids' exploitation of Ottoman subjects and thus would not allow it. Saray, Türkİran münâsebetlerinde Şiiliğin rolü 31 .

44 Ferīdūn Beg, Münşe’ātü's-selāțīn i, 328-329. Shah Ismāicil's second request, sent in 15021503, was, however, not accepted by the sultan. Solak-zâde, Solak-zâde Tarihi 429; Sümer, Safevi devletinin kuruluşu 26. 
toward the "heretical" practices of particular Kızllbaş communities as long as the sultan could rely on local notables and tribal and religious leaders to guarantee the communities' taxes. As Winter shows, among the first of Greater Syria's tribal leaders to pledge loyalty to Selìm I on his conquest of the region in $922 / 1516$ was the Kızllbaş family of Baalbek. ${ }^{45}$

Furthermore, in the following decades, Ottoman sultans tried to differentiate between "fiscally loyal" and "fiscally disloyal" Kızllbaş populations under their rule. As Stefan Winter notes in the case of the Kızılbaş families in Syria, Ottoman policy makers labeled Shi'ites as Kızlbaş not on account of heretical beliefs but to justify official violence in the cases of brigandage and tax evasion. ${ }^{46}$ Furthermore, in the Anatolian and Iraqi provinces, if a Kızlbaş individual or group remained peaceful and remitted their taxes, they were labeled only "Kızlbaş," whereas if they rebelled and/or refused to remit their taxes, additional pejorative labels were attached to them, such as mülhid, Räfìì, ehli fesād, bì-namāz or bed-mezheb. ${ }^{47}$ In a similar vein, Istanbul managed fiscal appointments in many parts of Anatolia in a way that the Kızllbaş who were in close contact with the Safavid court were punished more severely than the Kızılbaş who were not. An order from 977/1570, for instance, asked the governor of Baghdad not to assign mukātata'as, a type of tax farm, to Burç 'Alī and his peers in Mosul since they had been active on the frontier as Shi'i disciples (Rāfiż̄ serdār halîfeleri). ${ }^{48}$ Another decree sent to the governor of Divriği district (sancak), Mehmed Bey, in Șafer 976/August 1568 mentioned three halifes who were collecting money and goods for the Safavid shah. While one of them was caught and executed, the other two escaped to Safavid Iran. ${ }^{49}$ The anxiety of the Ottoman capital toward the financial power that the Kizllbas subjects possessed is also manifested in other ways. For instance, 17 of the 33 mühimme orders from 978/1570-1571 that mention Kızllbaş individuals or groups detail Selimm II's orders to local authorities to catch anyone providing financial support either to the shah's court or to the center of the order

45 Winter, The Kızılbaş of Syria 46.

46 For further examples of Ottoman financial support for various Kızılbaş subjects, Ibid.; Öz, Alevilik ile İlgili 147. For further information on the Shi'ites of Greater Syria under the Ottoman rule, see Abu Husayn, The Shiites in Lebanon. BOA, MD, Vol. 14, No. 311 (14 Safer 978/18 July 1570); MD, Vol. 14, No. 488 (12 Ramażān 978/7 February 1571).

48 MD, Vol. 9, No. 79 (29 Ramażān 977/7 March 1570).

49 Başbakanlık Osmanlı Arşivi, 7 Numaralı mühimme iii, 13-14, No. 1988 (1o Șafer 976/4 August 1568). The order pointed out that allowing them access to the public treasury, beyt'ül$m a \bar{l}$, was unlawful (cāiz olmaya) and, therefore, should be absolutely prevented (kat $t^{t} \bar{\imath}$ șūrette). 
in Ardabil. In addition, local authorities were told to confiscate money and valuables that were being sent to the shah. ${ }^{50}$ In many other cases, the flow of money was in the reverse, from the Safavid court to the Ottoman subjects, and Istanbul was equally anxious about it. An order from 987/1579 details Istanbul's concern over a transaction of 500 filori (Venetian ducats) between the Safavid state and Manșūr Halīfe of Tokat. The Kadis of nearby Zile and Artıkabad were sent to investigate this transaction and confiscate the money for the treasury. ${ }^{51}$

Ottoman central authority still applied the strategy of redistributing posts and benefits and granting privileged status to Safavid subjects who "turned" Sunni and/or moved to the Ottoman realm. However, these were fewer in number and mostly symbolic in Istanbul's counterpropaganda activities to win the "war of legitimacy" against the Safavid shahs. In one of the two noteworthy cases, Mehmed Sulțān, the Kuzılbaş governor of Qahqaha (Alamut) in northern Iran, took refuge in Istanbul in 995/1587, during the Ottoman-Safavid War of 986-999/1578-1590. In return for his loyalty to the Ottoman sultan and his help in conquering Ardabil, Mehmed Sulțān and his immediate family were promised high official positions. ${ }^{52}$ Changing sides (more than once in certain cases) between the Ottomans and Safavids was relatively common among Kuzılbaş emirs of the frontier regions. ${ }^{53}$ Mehmed Sulțann's migration to the Ottoman lands, however, was a sign of increasing Ottoman influence among the Kızlbaş emirs from the inner parts of Iran and left no choice for Shah

$5^{\circ}$ In an order from $978 / 1571$, the Ottoman central authority asked the governor of Baghdad to inquire into the nature of the communication between its Ottoman Kızllbaş subjects and the Safavid Kızilbaş who came to the Ottoman realm to collect alms and to confiscate these alms: "Yukarı Cānibden varanlara ne makūle kimesneler ihtilāṭ edip ve ne söyleşirler nuzūrr (nezir) ve șadakāt gibi nesne götürürler mi götüren ne așıl kimesnelerdir ve Yukarı Cānib adamları ne aṣıl kimesnelere mektūblarve armağan götürmüşlerdirve bi'l-cümle cemi ahvāllerine vākılf ve muțtali' olub șıhhati ile defter eyleyüb sana teslìm eyledikden șonra sen dahī te’hīr eylemeyüb Südde-i Sa'ādetime gönderesün." воА, MD, Vol. 14, No. 376 (9 Ramażān 978/4 February 4, 1571).

51 BOA, MD, Vol. 4O, No. 479 (28 Şacbān 987/20 October 1579).

52 BOA, MD, Vol. 63, Nos. 59 and 6o (2 Șefer 995/11 January 1587). Mühimme records mention other Kızılbaş emirs and their families who moved to the Ottoman Empire in response to the ongoing Ottoman counterpropaganda. For example, see MD, Vol. 65, No. 444 (3 SSefer 998/11 December 1589); Kırzıoğlu, Osmanlılar'ın Kafkas 378-379.

53 Monshī, however, singles out the Kurdish emirs for this behavior: "As in the custom of landowners in frontier areas, these men ["seditious Kurds"], as occasion demanded, from time to time attached themselves to the saddle straps of one of the rulers in the area and claimed to be his retainers, but their real motive was to stir up trouble and achieve their own ends in the ensuing confusion." Monshī, History of Shah 'Abbas 347. 
'Abbās but to sign a peace treaty with Istanbul in 998/1590.54 In a second case, an official decree from Ahmed I (r. 1012-1026/1603-17) granted the post of kapıcıbaşı, or chief doorkeeper, an honorary position typically given to converts, to a musician from the shah's court upon his conversion to Sunni Islam. ${ }^{55}$ Murād III (r. 982-1003/1574-1595) observed several staged conversions of Kızılbaş Iranians to Sunni Islam in the official circumcision ceremonies organized for his sons in 99o/1582. The miniatures of the court historian, or şehnāmeci, Seyyid Loḳmān's Şehnāme-i Selīm Hān ${ }^{56}$ and Şehnāme-i Murād-i Sālis, as well as İntizāāmìs Sūrnāme-i Hümāyūn, written for this occasion, depict the public conversion of many Kizllbaş during the festival. In one of the paintings, an Ottoman subject is depicted throwing off his Kuzllbaş turban in an attempt to gain the favor of the sultan, who is observing the scene from the balcony of the İbrahim Pasha Palace. ${ }^{57}$

\section{Ottoman Alienation of the Anatolian Population and the Issue of Migration}

The gradual integration of Anatolia into the Ottoman Empire was followed by tensions emerging between the Ottoman central authority and the nomadic and seminomadic populations, including small beylicates of the peninsula, largely because of the Ottoman policies of centralization, taxation, sedentarization, and displacement which caused long-lasting problems, including

54 "The presence of the Ottomans and the successful revolt of the Kurds encouraged others to rebel: among them was a tribe which had long enjoyed the favor of the Safavid royal house, and which resided in the Solduz and Mianduab districts of Maraga [an ethnically Turkish town in northwest Iran]." Ibid. 348-349.

55 BoA, Ali Emiri Tasnifi, I. Ahmed, File no. 7, Document no. 678 (1025/1616). Hülya Canbakal has analyzed the Ottoman registers of seyyids, or descendants of the Prophet, and suggested a link between the central authority's attempts to regulate the allotment of seyyid-hood and its policies of containment of the Kizllbass, for whom descent from the Prophet was particularly important. Canbakal, Society and politics in an Ottoman town 119, 61-90; Canbakal, The Ottoman state and descendants.

$5^{6}$ For a detailed study on the production process of Şehnāme-i Selìm Hān, see Fetvaci, The production.

57 Atasoy, 1582 Sūrnāme-i hümāyūn 111. For further details on Murād III's circumcision ceremony, see Zarinebaf-Shahr, Rebels and renegades; and Terzioğlu, The imperial festival. According to Mușțafa Ālī, the narrator of the festivities in the Sūrnāme-i hümāyūn, the Safavid convert was a hānzāde, the son of a prince, who was rewarded with an office following his conversion to Sunni Islam. Terzioğlu, The imperial festival 86. 
inflation, brigandage, and demographic fluctuations. ${ }^{58}$ Turcoman and Kurdish tribes were the main disadvantaged parties in this process, and as a result they came to distrust the Ottoman administration. Tension between the tribes and the Ottoman state was especially pronounced in eastern and southeastern Anatolia on account of relatively recent imposition of Ottoman control over the region, and the higher level of tribal influence and power compared to other parts of the peninsula. Furthermore, the state presence was closely associated with constant military struggles, shifting borders, and spying activities, ${ }^{59}$ which caused unrest among the dissatisfied and poorly organized rural populations who bore the bulk of the tax burden. The Celali Rebellions are often understood as a consequence of the tension between the tax-collecting state and the tax-paying subjects that accumulated in many parts of the peninsula and shook the state's authority for over a century. ${ }^{60}$

This tension, however, did not always culminate in outright rebellion, particularly when the disgruntled taxpayers had other options available. In fact, many locals, from both urban and rural environments, reacted to centralization and overtaxation by migrating to the Safavid realm either individually or as members of tribal groups, because of the Safavids' assurance of greater autonomy for them. In general, Safavids consistently promoted its subjecthood as a legitimate alternative to Ottoman taxpayer status. Imperial orders preserved in the mühimme registers reveal that the Anatolian tribes (and individuals) became more interested in relocating to the Safavid realm as they faced increasing financial pressure from the Ottoman capital, primarily after the turn of the tenth/sixteenth century, which corresponded with the emergence of the Safavid Empire as a powerful religiopolitical actor in the region.

Immediate responses of the Kizllbaş toward the adverse effects of the Ottoman centralization policies and their contribution to the success of pro-Safavid efforts in Anatolia can be clearly seen with the "tìmār system," which was implemented in the early ninth/fifteenth century in much of the Balkans (see Grigor Boykov's paper in this volume on the reactions toward Ottoman centraliza-

$5^{8}$ Faroqhi, Politics and socio-economic change 95. For further information on the tensions between the early Ottomans and various Anatolia beylicates, see Emecen, İlk Osmanlılar; Karadeniz, Osmanlılar ile beylikler arasında; Kafadar, Between two worlds 9o-117; Terzioğlu, Sufis in the age of state-building 89 .

59 For more information on the Ottoman tribal policy and the tribes in the eastern frontier zone, see Sinclair, The Ottoman arrangements.

6o For details on these rebellions, see Akdağ, Celali isyanları; Griswold, The great Anatolian rebellion; Tekindağ, Şahkulu Baba Tekeli isyanı; Şahin, Empire and power. The conventional scholarship has regarded these rebellions as the result of Safavid instigation. Uzunçarşıll, Osmanlı tarihi ii, 345-347; Saray, Türk-Irran münâsebetlerinde. 
tion policies in this region and their impact on religious dynamics) and in many parts of the Anatolian peninsula. ${ }^{61}$ While in principle timmärs were allocated based on merit rather than family connections and prestige, the quasihereditary nobility of certain tribes and families was able to dominate the system from its inception. ${ }^{62}$ In many instances, Istanbul used the distribution of timmär assignments as a tool to establish strong ties with local elites and "give them a stake in the Ottoman system" 63 so that they would not become disloyal to the Ottoman government. However, during the tenth/sixteenth and eleventh/seventeenth centuries, control of timmārs shifted from the entrenched tribal elite of the countryside, who had ties to the local population, to the urban elite. This process, combined with the increasingly oppressive behavior of the timār assessors, led to a sharp increase in dissidence among the rural population. ${ }^{64}$ Complaints concerning tīmār assignments begin to appear in primary sources as early as the 1510 . According to an official document from this period, the main reason for the Kızlbaş rebellion of Shah Kūlu in 916917/1511 was the unfair allocation of timārs to people from the inner circle of the palace and to local rulers, instead of meritorious cavalrymen ${ }^{65}$ In a similar vein, the tenth/sixteenth-century Ottoman statesman Celālzāde Mușțafa Çelebi (d. 975/1567) points out that Anatolians fled to the Safavid side in droves simply because of Bāyezīd II's negligence of his rural subjects, who were heavily oppressed by local authorities. ${ }^{66}$

The situation continued during the second half of the tenth/sixteenth century as well. ${ }^{67}$ As certain elite urban families monopolized timmār allocations, a

61 A tima $\bar{r}$ was a land grant, the revenue from which enabled the holder to outfit and support a number of cavalry forces and additional number of armed retainers (cebelï) for the Ottoman armies depending on the value and size of the land grant. Faroqhi, Politics and socio-economic change in the Ottoman Empire 94.

62 Haldon, The Ottoman state $55,62-63$.

63 Ibid. 55 .

64 Uzunçarşıll, Osmanlı tarihi ii, 333. Tribal leaders were not the only disgruntled group whose dissatisfaction with the system culminated in serious unrest. Beginning in the early ninth/fifteenth century, frontier warriors ( $g \bar{a} z \bar{\imath} \bar{s})$ and the Sufis connected to them were similarly victimized by Ottoman centralization efforts. The Sufis voiced their dissatisfaction with the ulama, the "agents, allies and beneficiaries of a centralizing state ... [filling] the medreses at an unprecedented rate" and, in some cases, sided with the Safavids. Kafadar, Between two worlds 90-117; Terzioğlu, Sufis in the age of state-building 89 .

65 Cited in Uluçay, Yavuz Sultan 53-9o.

66 Celâlzade, Selim-nâme $48 \mathrm{~b}-51 \mathrm{a}$.

67 Only ten percent of tīmārs were assigned to provincial cavalry soldiers in 16oo. Tezcan, The second Ottoman empire 22. 
divide grew between them, on the one hand, and tribal leaders and other members of the rural elite, on the other, who lacked the connections to acquire such grants and therefore felt betrayed by and alienated from the state. Celālzāde Muștafa mentions Anatolian tribes whose members migrated to Safavid Iran when they lost their privileged status and timārs in the 910s/1510s and 920s/ ${ }^{1520 s}{ }^{68}$ Peçevi similarly explains how the disenfranchisement of certain tribes led them to join regional rebellions. ${ }^{69}$

In the following decades, as more disgruntled timmār-holders and tribal leaders, both of whom Kaya Şahin aptly describes as "the perennial malcontents of Ottoman history,"70 as well as individuals seeking material gain and spiritual fulfillment, relocated to the Safavid realm, Istanbul began to pay increasing attention to these migrations. The Ottoman court frequently regarded these migrants as ignorant, lazy, or disloyal subjects who opposed the state for illegitimate reasons. In describing the influence of Safavid disciples in Anatolia, the Ottoman chronicler Kemālpaşazāde asserts that unemployed people who "had not achieved anything in their entire lives and who had no timärs" left their villages to join the haliffes with the false hope of becoming district governors on the Safavid side. ${ }^{71}$ Although Kemālpaşazāde is obviously biased against the Kızılbaş subjects of the Ottoman Empire and antagonistic toward the Safavids, he correctly points out that the oppressive timār policies of the Ottoman central authority and the lack of timār assignments to nonelites contributed significantly to the success of pro-Safavid efforts in early modern Anatolia.

In addition to witnessing "tremendous political and economic dynamism, a pervasive pragmatism, and an important level of social mobility and mobilization," ${ }^{72}$ the sixteenth century also marked the monetization of the Ottoman economy even further with the large-scale transformation from the timār system to tax farming. In response to these socioeconomic transformations, "money, which had always constituted the sinews of government, acquired an unprecedented significance for the Ottoman administrative military apparatus, which seemed to need it more than ever."73 The central administration's dire need for cash and, as a result of advances in military technology, declining need for cavalry resulted in a sharp decline in timmär assignments and a

\footnotetext{
68 Savaş, XVI. Asırda Anadolu'da Alevilik 59, 156.

69 Peçevī, Peçevi Tarihi i, 94.

70 Şahin, Empire and power 125.

71 Kemālpaşazāde, Tevārih-i Âl-i Osmān ix, Süleymaniye Kütüphanesi, Ms Fatih 4221, 198a, cited in Uğur, The reign of Sultan Selìm I 43.

72 Şahin, Empire and power 10.

73 Tezcan, The second Ottoman empire 11.
} 
corresponding increase in tax farms (iltizām). Many Kızılbaş Anatolians felt cheated by this transformation on account of corruption and overtaxation. They also suffered from the effects of the general late tenth/sixteenth-century crisis, notably population pressure and climate change. ${ }^{74}$

Both empires were fully aware of the fiscal power of the Kuzılbaş, and this concern became manifested in the peace treaties signed between the two capitals. Istanbul reciprocated Safavid efforts at keeping the peace treaties intact by enforcing their articles, particularly in the frontier regions. For instance, while Sunni Iranians were not allowed to migrate to the Ottoman realm, official orders sent from Istanbul called for the investigation and punishment of Ottoman individuals or groups who violated the agreement between the two empires as well. ${ }^{75} \mathrm{~A}$ series of imperial orders, likewise, warn the governor of Van to pay utmost attention to and prevent any type of infringement of the Amasya Peace Treaty following rumors of Ottoman subjects attacking the Safavids and plundering their land and property. These orders ultimately asked the governor to find and to punish severely the violators harming the Safavid frontier tribes of Brados and Lityan, after mentioning that the Safavids have been fulfilling their responsibilities. ${ }^{76}$ Furthermore, countless imperial orders requested the Ottoman authorities in central and eastern Anatolia to stop these migrations. A series of orders from the $960 \mathrm{~s} / 1560 \mathrm{os}$, for instance, demanded from the rulers of Amasya, Tokat, and Çorum, heavily Kuzılbaş towns in north central Anatolia, to investigate the large numbers of migrants, some of whom had been stopped in Erzurum in northeastern Anatolia and barred from entering

74 Ibid. 17. Sam White convincingly argues that the suitable ecological environment of the first half of the tenth/sixteenth century allowed the Ottoman central authority to pursue expansionist policies, to create an Ottoman elite class, and to forge ahead with state formation. However, as the state apparatus grew, "Ottoman systems of provisioning and settlement faced mounting problems. Just as the Ottomans proved especially precocious at building these systems, so they became particularly dependent on their stability and susceptible to their failures," particularly during the critical periods of "population pressure, inflation, and diminishing returns from agriculture" from the $9705 / 1570$ os to the 99 os/159os. White, The climate of rebellion 19.

75 For examples, see Başbakanlık Osmanlı Arşivi, 3 Numaralı mühimme 517-518, No. 1168 (966-968/1558-156o); Başbakanlık Osmanlı Arşivi, 5 Numaralı mühimme 270, No. 1721 (10 Zilkạa'de 973/29 May 1566).

76 "Mādām ki ol cānibden șulh ve șalāha mugāyir vaż's șādır olmağa bu cānibden bir ferde șulh ve emāna muhālif iş eylemekten ihtìyāt eyleyib șulh ve șalāḥ umūrun gereği gibi ricāyet eyleyüb." вOA, MD, Vol. 14, No. 756 (28 Cemāziyülāhır 978/27 November 1570). The same order, however, asks the governor to keep sending "useful and civilized" (yārār ve mütemeddin) spies to Safavid Iran. See also BOA, MD, Vol. 18, No. 57 (29 Ramażān 979/14 February 1572). 
the Safavid realm. ${ }^{77}$ In another order from the late 156 os, the ruler of Trabzon was cautioned about the increasing risk of the entire Kizllbaş population migrating to Safavid Iran if their relations with the Safavid court were not cut off immediately. ${ }^{78}$ While many of these orders do not specify individuals and their attempts to migrate to Safavid Iran, others address specific local elites and tribes, whose migration had a greater impact on both sides. For instance, Istanbul repeatedly warned the governor of Erzurum about the Turcoman Batlu tribe from Ardahan, whose leader fled to the "other side," ordering him to stop the tribe's members from following their leader and to find and execute the leader himself. ${ }^{79}$ The leader of the Kurdish Belilhānoğulları tribe from the Van/ Tabriz region, for instance, migrated to the Safavid side and sought help from Shah 'Abbās I in 1010-1011/16o2. The Ottoman governor of Tabriz, 'Alī Pasha, responded by provoking a military conflict between the two sides that resulted in the occupation of Tabriz by the Safavids in 1012/1603. ${ }^{80}$

As Robert Hefner asserts, early modern communities "burdened with a sense of oppression and powerlessness [were] in need of ... social redemption, that is, a state that provides relief from an intolerable situation through new morality and social relations." 81 As mentioned above, the emergence of the Safavid Empire right next door to Anatolia and the formation of a new religiopolitical identity around the Safavid Sufi order provided Anatolians with a legitimate political and territorial alternative. Celālzāde Mușțafa, in his Țabakătüllmemālik ve derecātü'l-mesālik, describes this period, with his typically strong anti-Safavid prejudice, as one in which "a band of naked dervishes, runaway Turkish peasants, and heretics” (bir bölük çıplak ışıklar, çiftbozan Türkler, münāfiklar) attacked sharia and ḳānūn and killed Sunnis under the influence of the "sharia-abrogating and sedition-filled East" (şark-ı şer-fark ve fitne-gark. ${ }^{82}$ Despite his gross generalization and open hostility against the Safavids and their Anatolian sympathizers, the Kızlbaş, indeed, became not only an object of the Ottoman-Safavid competition but also an active participant and contributor to it. ${ }^{83}$ On occasion, various Safavid actors, disguised as merchants or travelers, orchestrated these migrations. For instance, Istanbul warned the governor of Baghdad in 980/1573 about a certain Sohrāb who had entered Ottoman

\footnotetext{
77 Başbakanlık Osmanlı Arşivi, 3 Numaralı mühimme 63o, No. 1422 (Zillka'de 967/August 1560).

78 Başbakanlık Osmanlı Arşivi, 5 Numaralı mühimme 221, No. 1401 (973/1565).

79 BOA, MD, Vol. 21, No. 110 (19 Ramażān 980/23 January 1573).

$80 \quad$ Saray, Türk-İran Münâsebetlerinde 38.

81 Hefner, World building 29.

82 Cited in Şahin, Empire and power 69-71, 90-91.

83 Dressler, Inventing orthodoxy 153.
} 
territory allegedly to fetch the daughter of a Safavid regional ruler but instead took many members of a local tribe back to Iran with him. ${ }^{84}$ As another precaution against this type of migration, Istanbul several times asked local authorities not to let the Safavid Iranians mingle with the locals when they visited their towns for trade or pilgrimage. ${ }^{85}$ Within a short period, however, thousands whose dissatisfaction stemmed from financial devastation, the lack of sustainable revenues, and overtaxation decided to relocate as the Safavid realm promised less taxation, more autonomy, and salvation through allegiance to a messianic ruler. According to Rudi Matthee, the Safavid shahs from the beginning attempted to build a state on the notions of "shared religion, a long legacy of strong personalized authority, and a governmental tradition centering on royal justice and commercial activism." 86

These migrations meant not only the loss of population, but also the loss of income and goods, which in many cases were more crucial for the Ottoman court, which led to a flurry of imperial orders attempting to stop the outflow. ${ }^{87}$ In one order from $982 / 1574$, the sultan asked the governor of Van to stop the migration of the Haledi tribe, who had been paying their dues and taxes $(h u k \bar{u} k$. ve rüsümları) to the Ottomans, to the Safavid territory. In many instances, Istanbul also asked the Safavid court to send back Ottoman subjects who had already migrated. ${ }^{88}$ Istanbul justified these requests by invoking the Peace of Amasya, which banned migrations from one side to the other. ${ }^{89}$ For instance, in an order from 1574, the sultan told the governor-general of Baghdad to accept those who had moved to Safavid Iran and come back following the peace, regardless of their sect (madhhab). ${ }^{90}$

84 BOA, MD, Vol. 21, No. 697 (29 Zilhicce 980/2 May 1573).

85 BOA, MD, Vol. 23, No. 43 (29 Zilhicce 981/21 April 1574); MD, Vol. 24, No, 124 (29 Zilkade 981 /23 March 1574).

86 However, decentralizing forces ("formidable mountain regions, fearsome deserts, a harsh climate, long distances, and a thinly spread and largely nomadic population," as well as "the lack of an effective infrastructural state power"), prevented a strong state from materializing. Matthee, The politics of trade 232.

87 For an earlier discussion on this topic, see Allouche, The origins and development. Allouche rightfully emphasized the importance of trade for both the Ottoman and Safavid courts and the consecutive attempts to secure them with various policies that included signing agreements and dispatching envoys on the one hand and closely monitoring trade-related activities and punishing those who acted against the rules and regulations on the other. BOA, MD, Vol. 26, No. 496 (10 Cemāziyelevvel 982/27 August 1574).

89 BOA, MD, Vol. 26, No. 78 (28 Șefer $982 / 18$ June 1574).

90 BOA, MD, Vol. 26, No. 958 (14 Şa'bān $982 / 28$ November 1574). The following orders warn the governor-general of Baghdad not to send the returnees back to Iran even if the Safavid court requests it. For an example, see BOA, MD, Vol. 26, No. 974 (15 Şa bān 982/29 November 1574). 
As the Ottoman-Safavid rivalry turned into a conflict shaped by sectarian narratives, the religious and political identities of the subjects between the two emerging empires became closely intertwined. The increasing sympathy for the Safavids among the Ottoman subjects, however, did not stem solely from confessional priorities of those seeking salvation through becoming the followers of the shah. The regions from which the largest number of people converted to Kızılbaşism and \or migrated to Safavid Iran were usually those experiencing economic problems or political disturbances, mostly deriving from the policies of the Ottoman central authority. In other words, various worldly concernssociopolitical and fiscal pressures or enticements, the loss or prospect of posts and pensions - constituted significant motives behind becoming or remaining a Kızılbaş in the early modern Ottoman realm. This dynamic created a horizontal power relation between the Ottoman imperial center and its subjects, in which the power holder status of the Kızlbaş manifested itself as a combination of multifarious decisions taken against (or for) the central authority and its representatives in the provinces. In these interactions, many Kızılbaş individuals and groups acted as mediators, negotiators, facilitators, and also as rebels.

This article has also demonstrated the complexity of the interactions among the three major participants in this specific geopolitical environment (i.e., the Ottoman and Safavid courts and the Kızlbaş) that went beyond the conventional Sunni-Shi'i division. The cases provided here, as a small sample from a larger pool, provide us with strong indicators of the nature of the relationship between the Ottoman central authority vis-à-vis its Kızlbaş subjects, as well as the constant efforts made by both the Ottomans and Safavids to retain this population's loyalty. By contextualizing and historicizing the actions taken by the Kızllbaş, these cases display the enmeshment of sectarian policies with the oft-neglected issues of political, religious, and fiscal motivations in interconfessional and interimperial contact zones. From this angle, one can see the utility of approaching this history "laterally" as opposed to top-down or bottom-up approaches that imagine the relations between the ruler and the ruled in terms of vertical relations of power. Last but not least, the increase in punitive actions and persecutions that the Ottoman central authority took against the Kızılbaş subjects of the empire should be scrutinized within this context. In other words, in the eyes of Istanbul, the conversion, tax evasion, and migration of its subjects to Safavid Iran represented the loss of a critical part of the empire's work force, and the Kızlbaş population(s) was fully aware of this. While the Ottoman central and provincial authorities dealt with them through 
multifaceted policies (from offering new titles, land autonomy, and tax exemption on the one end, to heavy persecution on the other), fiscally and politically motivated conversions and/or migrations to and from Safavid Iran constituted a significant aspect of the early modern era and continued until the beginning of the twelfth/eighteenth century, albeit with decreasing intensity. ${ }^{91}$

\section{Bibliography}

\section{Primary Sources}

вОA: Başbakanlık Osmanlı Arşivi [now T.C. Cumhurbaşkanlığı Devlet Arşivleri Başkan$\operatorname{lnğ} 1]$

Cevdet Tasnifi, Document No. 922-39839, (2o Ramażān 96o/3o August 1553)

Ali Emiri Tasnifi, I. Ahmed, File no. 7, Document no. 678 (1025/1616). MD (Mühimme Defterleri), Volumes 9, 14, 18, 21, 24, 25, 26, 35, 40, 63, 65.

Başbakanlı Osmanlı Arşivi, 3 Numaralı mühimme defteri, 966-968/1558-156o, eds. N. Aktaș and N. Gültepe, 2 vols., Ankara, 1993.

Başbakanlık Osmanlı Arşivi, 5 Numaralı mühimme defteri, 973/1565-1566, eds. N. Aktaș and N. Gültepe, Ankara, 1994.

Başbakanlık Osmanlı Arşivi, 7 Numaralı mühimme defteri, 975-976/1567-1569, eds., N. Aktas and N. Gültepe, 2 vols., Ankara, 1999.

Atasoy N., 1582 Surname-i Hümayun: An imperial celebration, Istanbul 1997.

Ayylldı, H. (ed.), Buyruk, İmamı Cafer Buyruğu: Hakiki Din Yolu, Ankara 2002.

Baştav, S. (trans. and ed.), 16. asırda yazılmış Grekçe Anonim Osmanlı tarihi, Ankara 1973. Bisâtî, Şeyh Sâfí Buyruğu, ed. A. Taşgin, Istanbul 2013.

Bidlisi, S., The Sharafnâma or the History of the Kurdish Nation, trans. and ed. M.R. Izady, Costa Mesa 2005 .

Celâlzade Mustafa Çelebi, Selim-nâme, ed. A. Uğur, Istanbul 1997.

Ferīdūn Beg, Münşe'ātü's-selāțīn, 2 vols., Istanbul 1857.

Kaplan, D., Şeyh Safi buyruğu, Istanbul 2015.

Karakaya-Stump, A., Kızılbaş, Bektaşi, Safevi ilişkilerine dair 17. yüzyldan yeni bir belge: Çeviriyazılı metin-çeviri-tıpkıbasım, in Y. Dağlı et al. (eds.), Festschrift in honor of Orhan Okay, a special issue of the Journal of Turkish studies 30 (2006), 117130 .

91 Selim Güngörürler's article in this volume provides us with a clear picture concerning the political interactions between the Ottoman and Safavid courts from the mid-seventeenth century until the end of the Safavids in the 1720 s. 
Monshī, Eskandar Beg, History of Shah 'Abbas the Great, 3 vols., trans. and ed. R. Savory, Boulder 1978 .

Musalı, N., Şeyh Safi velâyetnâmesi: Tahkiki ve transkripsiyonu, in Türk kültürü ve Hacı Bektaş Veli araştırma dergisi 84 (2017), 163-193.

Solak-zâde, M.H.Ç., Solak-zâde Tarihi, ed. V. Çabuk, Ankara 1989.

\section{Secondary Sources}

Abbaslı, M., Safevilerin kökenine dair, in Belleten (1976), 287-329.

Abu Husayn, A., The Shiites in Lebanon and the Ottomans in the 16th and 17th centuries, in Convegno sul Tema: La Shïa nell'Impero Ottomano, Roma 1993, 107-119.

Ágoston, G., A flexible empire: Authority and its limits on the Ottoman frontiers, in International journal of Turkish studies 9 (2003), 15-31.

Akdağ, A., Celali isyanları: Türk halkının dirlikve düzenlik kavgası, Istanbul 2009 [originally published in 1963].

Allouche, A., The origins and development of the Ottoman-Safavid conflict (906-962) 1500-1555), Berlin 1983.

Anooshahr, A., Turkestan and the rise of Eurasian empires: A study of politics and invented traditions, Oxford 2018.

Arjomand, S., The shadow of God and the hidden imam: Religion, political order and societal change in Shi'ite Iran from the beginning to 1890, Chicago 1984.

Ateş, S., Ottoman-Iranian borderlands: Making a boundary, 1843-1914, Cambridge 2013.

Baha Said Bey, Türkiye'de Alevi-Bektaşi, Ahi ve Nusayri zümreleri, ed. İ. Görkem, Ankara 2000.

Baltacıoğlu-Brammer, A., The emergence of the Safavids as a mystical order and their subsequent rise to power in the fourteenth and fifteenth centuries, in R. Matthee (ed.), The Safavid world, London, 2021 (forthcoming).

Baltacıoğlu-Brammer, A., The formation of Kızlbaş communities in Anatolia and Ottoman responses, 1450s-163os, in International journal of Turkish studies 20 (2014), $21-48$.

Baltacıoğlu-Brammer, A., "Those heretics gathering secretly ...:" Qizilbash rituals and ceremonies according to early modern Ottoman sources, in Journal of Ottoman and Turkish studies association 6 (2019), 39-6o.

Baltacıoğlu-Brammer, A., One word, many implications: The term "Kızılbaş" in the early modern Ottoman context, in V. Erginbaş (ed.), Ottoman Sunnism: New perspectives, Edinburg 2019, 47-70.

Bardakçı, C., Alevilik Ahilik Bektaşilik, Istanbul 2012.

Bashir, S., Deciphering the cosmos from creation to apocalypse: The Hurufiyya movement and medieval Islamic esotericism, in. A. Amanat and M. Bernhardsson (eds.), Imagining the end: Visions of apocalypse from the ancient Middle East to modern America, London 2002, 168-182. 
Bashir, S., Messianic hopes and mystical visions: The Nürbakhshīya between medieval and modern Islam, Columbia, sc 2003.

Birdoğan, N., Alevi kaynakları, Istanbul 1999.

Birdoğan, N., Anadolu ve Balkanlar'da Alevi yerleşimleri, Istanbul 1995.

Brummet, P., Mapping the Ottomans: Sovereignty, territory, and identity in the early modern Mediterranean, London 2015.

Bulliet, R.W., Conversion to Islam in the medieval period: An essay in quantitative history, Cambridge, MA 1979 .

Burak, G., The second formation of Islamic law: The Hanafi school in the early modern Ottoman Empire, New York 2015.

Cahen, C., Le problème du Shî'isme dans l'Asie Mineure turque préottomane, in R. Brunschvig and T. Fahd (eds.), Le Shîisme Imâmite: Colloque de Strasbourg (69 Mai 1968), Paris 1970, 115-129.

Canbakal, H., Society and politics in an Ottoman town: 'Ayntab in the 17th Century, Leiden 2006.

Canbakal, H., The Ottoman state and descendants of the Prophet in Anatolia and the Balkans (c. 1500-1700), in JESHO $5^{2}$ (2009), 542-578.

Dressler, M., Inventing orthodoxy: Competing claims for authority and legitimacy in the Ottoman-Safavid conflict, in H.T. Karateke and M. Reinkowski (eds.), Legitimizing the order: The Ottoman rhetoric of state power (OEH 34) Leiden 2005, 151-173.

Dressler, M., Writing religion: The making of Turkish Alevi Islam, Oxford 2013.

Ebel, K.A., Representation of the frontier in Ottoman town views of sixteenth century, in Imago mundi 6o (2008), 1-22.

Eberhard, E., Osmanische Polemik gegen die Safawiden im 16. Jahrhundert nach arabischen Handschriften, Freiburg 1970.

Emecen, F.M., İlk Osmanlılarve Batı Anadolu beylikler dünyası, Istanbul 2001.

Erginbaş, V., Problematizing Ottoman Sunnism: Appropriation of Islamic history and ahl al-baytism in Ottoman literary and historical writing in the sixteenth century, in JESHO 6o (2017), 614-646.

Eröz, M., Türkiye'de Alevilikve Bektaşilik, Ankara 199 o.

Faroqhi, S. Politics and socio-economic change in the Ottoman Empire of the later sixteenth century, in M. Kunt and C. Woodhead (eds.), Süleyman the Magnificent and his age: The Ottoman Empire in the early modern world, London 1995, 91-111.

Fetvaci, E. The production of Şehnāme-i Selìm Hān, in Muqarnas 26 (2009), 263-315.

Fleischer, C., The Lawgiver as Messiah: The making of the imperial image in the reign of Süleymân, in G. Veinstein (ed.), Soliman le Magnifique et son temps, Paris 1992, 159-177.

Fuccaro, N., The Ottoman frontier in Kurdistan in the sixteenth and seventeenth centuries, in C. Woodhead (ed.), The Ottoman world, London 2011, 237-250.

Glassen, E., Bedlīsī, Šaraf-al-Dīn Khan, in EIr, iv, 76-77. 
Griswold, W., The great Anatolian rebellion, 100-1020/1591-1611, Berlin 1983.

Günaltay, M.Ş., Türk-İslam tarihine eleştirel biryaklaşım: Maziden Atiye, Ankara 2003.

Haldon, J., The Ottoman state and the question of state autonomy: Comparative studies, in H. Berktay and S. Faroqhi (eds.), New approaches to state and peasant in Ottoman history, London 1992, 18-108.

Hefner, R.W., World building and the rationality of conversion, in R.W. Heffner (ed.), Conversion to Christianity: Historical and anthropological perspectives on a great transformation, Berkeley 1993, 3-44.

Heywood, C., The frontier in Ottoman history: Old ideas and new myths, in D. Power and N. Standen (eds.), Frontiers in question: Eurasian borderlands, 700-1700, London 1999, 228-25o.

Hinz, W. Uzun Hasan ve Şeyh Cüneyd, Ankara 1992.

İnalcık, H., Ottoman methods of conquest, in SI 2 (1954), 103-129.

Imber, C., The persecution of the Ottoman Shi'ites according to the mühimme defterleri, 1565-1585, in Der Islam $5^{6}$ (1979), 245-273.

Jennings, R., Christians and Muslims in Ottoman Cyprus and the Mediterranean world, 1571-1640, New York 1992.

Kafadar, C., Between two worlds: The construction of the Ottoman state. Berkeley, Los Angeles 1995 .

Kaplan, D., Yazılı kaynaklara göre Alevilik, Istanbul 2019.

Karadeniz, H.B., Osmanlılar ile beylikler arasında Anadolu'da meşruiyet mücadelesi (XIV-XVI. Yüzyıllar), Istanbul 2008.

Karakaya-Stump, A., Documents and Buyruk manuscripts in the private archives of Alevi Dede families: An overview, in BJMES 37 (2010), 273-286.

Karakaya-Stump, A., The Kizilbash-Alevis in Ottoman Anatolia: Sufism, politics and community, Edinburg 2019.

Karamustafa, A.T., Origins of Anatolian Sufism, in A.Y. Ocak (ed.) Sufis and Sufism in Ottoman society: Sources, doctrines, rituals, turuq, architecture, literature and fine arts, modernism, Ankara 2005, 67-95.

Kılıç, O., Yurtluk-ocaklık ve hükümet sancaklar üzerine bazı tespitler, in Ankara Üniversitesi Osmanlı tarihi araştırma ve uygulama merkezi dergisi 10 (1999), 119-139.

Kırzıoğlu, F., Osmanlılar'ın Kafkas ellerini fethi (1451-159o), Ankara 1976.

Kołodziejczyk, D., Between universalistic claims and reality: Ottoman frontiers in the early modern period, in C. Woodhead (ed.), The Ottoman world, London 2011, 205219.

Köprülü, M.F., Türk edebiyatı'nda ilk mutasavvıflar, Ankara 1981.

Kütükoğlu, B., Osmanlı: Iran siyasi münasebetleri (1578-1612), Istanbul 1993.

Markiewicz, C., The crisis of kingship in late medieval Islam:Persian emigres and the making of Ottoman sovereignty, New York 2019.

Matthee, R.P., The politics of trade in Safavid Iran: Silk for silver 1600-1730, Cambridge 1999. 
Mazzaoui, M.M., The origins of the Șafavids: Šìism, Șūfism and the Gulāt, Wiesbaden 1972.

Mélikoff, I., Uyur idik uyandırdılar, trans. T. Alptekin, Istanbul 1994.

Minkov A., Conversions to Islam in the Balkans: Kisve bahasipetitions and Ottoman social life, 1670-1730, Boston 2004.

Minorsky, V., Shaykh Bali-Efendi on the Safavids in BSOAS 20 (1957), 437-45O.

Musalı, N., Şeyh İbrahim Safevi döneminde Erdebil tekkesi, in Türk kültürüve Hacı Bektaş Veli araştırma dergisi 8o (2016), 9-30.

Ocak, A.Y., Babailer isyanı, Istanbul 1980.

Ocak, A.Y., Alevi ve Bektaşi inançlarının İslam öncesi temelleri, Istanbul 2000.

Ocak, A.Y., Din ve Düşünce, in E. İhsanoğlu (ed.), Osmanlı devleti ve medeniyeti tarihi, vol. 2, Istanbul 1998, 107-194.

Ocak, A.Y., Syncrétisme et esprit messianique: le concept de “Qotb” et les chefs des mouvements messianiques aux époques seldjoukide et ottomane (XIIIe-XVIIe siècle), in G. Veinstein (ed.), Syncrétismes et hérésies dans l'Orient seldjoukide et ottoman, Leiden 2005, 249-257.

Öz, B., Alevilik ile ilgili Osmanlı belgeleri, Istanbul 1995.

Özel, O., Population changes in Ottoman Anatolia during the 16th and 17th centuries: The "demographic crisis" reconsidered, IJMES 36 (2004), 183-205.

Peacock, A.C.S. (ed.), The frontiers of the Ottoman world, Oxford 2009.

Pfeiffer, J., Confessional ambiguity vs. confessional polarization: Politics and the negotiation of religious boundaries in the Ilkhanate, in J. Pfeiffer (ed.), Politics, patronage and the transmission of knowledge in 13th-15th century Tabriz, Leiden 2014, 129-168.

Pourmoḥammadī Āmleshī, N. and B. Zeylābpour, Sheikh Ibrāhīm Ṣafavī morshid-ī ghomnām, in Faṣlnāme-ye 'ilm-ī pajuhash-ī tārīkh 3 (1387), 35-56.

Radushev, E., The spread of Islam in the Ottoman Balkans: Revisiting Bulliet's method on religious conversion, Oriental archive 78 (2010), 363-384.

Riyāḥ̄, M.Ā., Sefāratnāmehā-ye Īrān: Gozāreshha-ye mosāferat ve māmurīyat-e safirāne ‘Osmānī dar Īrān, Tehran 1368/1989.

Roemer, H.R., The Qizilbash Turcomans: Founders and victims of the Safavid theocracy, in M.M. Mazzaoui and V.B. Moreen (eds.), Intellectual studies on Islam: Essays written in honor of Martin B. Dickson, Salt Lake City 199o, 27-39.

Saray, M., Türk-İran münâsebetlerinde şiiliğin rolü, Ankara 1990.

Savaş, S., XVI. asırda Anadolu'da Alevilik, Istanbul 2002.

Schwarz, F., Writing in the margins of empire: The Husaynabadi family of scholiasts in the Ottoman-Safavid borderlands, in T. Heinzelmann and H. Sievert (eds.), Buchkultur im Nahen Osten des 17. und 18. Jahrhunderts, Bern 2010, 151-198.

Sinclair, T., The Ottoman arrangements for the tribal principalities of the Lake Van region in the sixteenth century, in K.H. Karpat and R.W. Zens (eds.), Ottoman borderlands: Issues, personalities and political changes, Madison 2003, 119-143. 
Subrahmanyam, S., Turning the stones over: Sixteenth-century millenarianism from the Tagus to the Ganges, in Indian economic and social history review 40 (2003), 129116.

Sümer, F., Safevidevletinin kuruluşuve gelişmesinde Anadolu Türklerinin rolü (Şah İsmail ile halifeleri ve Anadolu Türkleri), Ankara 1976.

Şahin, K., Empire and power in the reign of Süleyman: Narrating the sixteenth-century Ottoman world, Cambridge 2013.

Tekindağ, Ş., Şahkulu Baba Tekeli isyanı, in Belgelerle Türk tarihi dergisi 1 (1967), 36-61.

Terzioğlu, D., How to conceptualize Ottoman Sunnitization: A historiographical discussion, in Turcica 44 (2012-2013), 301-338.

Terzioğlu, D., The imperial festival of 1582: An interpretation, in Muqarnas 12 (1995), 84-100.

Terzioğlu, D., Sufis in the age of state-building and confessionalization, in C. Woodhead (ed.), The Ottoman world, London 2012, 86-99.

Tezcan, B., The development of the use of "Kurdistan" as a geographical description and the incorporation of this region into the Ottoman Empire in the 16th century, in K. Çiçek (ed.), The great Ottoman-Turkish civilization, iii, Ankara 2000, 540-553.

Tezcan, B., The second Ottoman Empire: Political and social transformation in the early modern world, Cambridge 2010.

Uğur, U., The reign of Sultan Selìm I in the light of the Selïm-näme literature, Berlin 1985. Uluçay, Ç., Yavuz Sultan Selim nasıl padişah oldu? in Tarih dergisi 6 (1954), 53-9o.

Uzunçarşılı, I.H., Osmanlı tarihi, ii, Istanbul'un fethinden Kanuni Sultan Süleyman'in ölümüne kadar, Ankara 1943.

White, S., The climate of rebellion in the early modern Ottoman Empire, Cambridge 2011.

Winter, S., The Kızılbaş of Syria and Ottoman Shiism, in C. Woodhead (ed.), The Ottoman world, London 2011, 171-183.

Winter, S., The Shiites of Lebanon under Ottoman rule, 1516-1788, Cambridge 2010.

Woods, J., The Aqquyunlu: Clan, confederation, empire, Salt Lake City 1999.

Yaman, M. (ed.), Buyruk-Alevi inanç_ibadet ve ahlak ilkeleri, Istanbul 2013.

Yıldırım, R., Geleneksel Alevilik: Inanç, ibadet, kurumlar, toplumsal yapı, kollektif bellek, Istanbul 2018.

Yıldırım, R., Sunni orthodox vs Shi'ite Heterodox? A reappraisal of Islamic piety in medieval Anatolia, in A.C.S. Peacock, B. De Nicola and S.N. Yıldız (eds.), Islam and Christianity in medieval Anatolia, London 2015, 287-307.

Yılmaz, H., Caliphate redefined: The mystical turn in Ottoman political thought, Princeton 2018.

Zarinebaf, F., Rebels and renegades on Ottoman-Iranian borderlands: Porous frontiers and hybrid identities, in A. Amanat and F. Vejdani (eds.), Iran facing others: Identity boundaries in a historical perspective, New York 2012, 79-97.

Zarinebaf, F., Qizilbash "heresy" and rebellion in Ottoman Anatolia during the sixteenth century, in Anatolia moderna 7 (1997), 1-15. 